\title{
DNA demethylation modulates mouse leptin promoter activity during the differentiation of 3T3-L1 cells
}

\author{
N. Yokomori, M. Tawata, T. Onaya \\ Third Department of Internal Medicine, Yamanashi Medical University, Tamaho, Yamanashi, Japan
}

\section{Abstract}

Aims/hypothesis. The mouse leptin gene, a major hormonal regulator of appetite and fat cell mass, expresses during the differentiation of 3T3-L1 preadipocytes to adipocytes. To determine if DNA methylation is involved in regulating the expression of the leptin gene, we examined the methylation status and methylation-sensitive transcription factors during 3T3-L1 differentiation.

Methods. DNase I footprinting, electrophoretic mobility-shift assays, and a Southwestern analysis were carried out using nuclear extracts from preadipocytes and adipocytes. Promoter activity was measured by luciferase assays. The $\mathrm{CpG}$ methylation pattern was determined.

Results. Transient transfection of reporter constructs with the leptin promoter showed that preadipocytes that do not transcribe the leptin gene show enough transactivation, suggesting the presence of an additional regulatory mechanism. We identified eight
CpG sites in the promoter up to $\mathrm{nt}-161$, all of which were highly methylated ( $>92 \%$ ) in preadipocytes. Seven of these sites showed a varying degree of demethylation during differentiation, while the site at nt -54 remained methylated. In electrophoretic mobilityshift assays, DNA fragments from $\mathrm{nt}-115$ to $\mathrm{nt}-70$ generated a methylation-sensitive band with nuclear extracts from preadipocytes when the $\mathrm{CpG}$ sites were methylated. Southwestern analysis identified a 52 $\mathrm{kM}_{\mathrm{r}}$ protein that binds strongly to the methylated probes. Promoter activity was reduced by methylation of the CpG sites up to $\mathrm{nt}-115$, but not up to $\mathrm{nt}-70$. Conclusion/interpretation. These results suggest that methylation of specific $\mathrm{CpG}$ sites between $\mathrm{nt}-115$ and $\mathrm{nt}-70$ and a methylation-sensitive protein could contribute to leptin gene expression during adipocyte differentiation in 3T3-L1 cells. [Diabetologia (2002) 45: 140-148]

Keywords Leptin, methylation, CpG site, 3T3-L1 cells, methyl-CpG-binding proteins.
During the differentiation of 3T3-L1 preadipocytes to adipocytes, transcriptional activators and repressors regulate the expression of many adipocyte-spe-

Received: 19 January 2001 and in revised form: 10 September 2001

Corresponding author: N. Yokomori, Third Department of Internal Medicine, Yamanashi Medical University, Tamaho, Yamanashi 409-3898, Japan,

e-mail: yokomori@res.yamanashi-med.ac.jp

Abbreviations: EMSA, Electrophoretic mobility-shift assays; $\mathrm{C} / \mathrm{EBP}$, CCAAT/enhancer-binding protein; CED, $\beta$-cyanoethyl-N, N-diisopropylamino; DTT, dithiothreitol; FBS, fetal bovine serum cific genes [1-4]. In addition, DNA methylation could also play an important role during the process of adipocyte differentiation. We recently showed that methylation of specific CpG sites of the GLUT4 gene and a methylation sensitive transcription factor, contribute to GLUT4 gene regulation during 3T3-L1 differentiation [5]. Similar mechanisms could also regulate the expression of other genes induced during adipocyte differentiation.

Leptin, a major hormonal regulator of appetite and fat cell mass, is one of these adipocyte-specific genes $[6,7]$. It is secreted by adipose tissue in response to a high content of body fat. Thus, mice lacking a functional leptin gene develop hyperphagia, hy- 
perglycemia, hyperinsulinemia, and obesity [8]. Since circulating leptin concentrations correlate with the amount of body fat, the regulation of the leptin gene expression is critical in maintaining normal body fat content. Expression of the leptin gene has been found to be induced during the differentiation of 3T3-L1 preadipocytes into adipocytes [9]. Like other adipocyte-specific genes, the leptin gene is regulated by $\mathrm{CCAAT} /$ enhancer binding protein $\alpha(\mathrm{C} / \mathrm{EBP} \alpha)[10$, 11]. Recently, Sp1 and Lp1 also have been reported to be enhancers [12].

To determine if DNA methylation is involved in the regulation of the leptin gene expression, we examined DNA methylation and methylation-sensitive transcription factors during the differentiation of 3T3-L1 cells from preadipocytes to adipocytes.

\section{Materials and methods}

Cell culture. 3T3-L1 cells [American type culture collection (ATCC), Manassas, Va., No.CCL 92.1] were grown in high glucose DMEM supplemented with $10 \%$ calf serum. Confluent 3T3-L1 preadipocytes were induced to differentiate into adipocytes as described [13]. Briefly, 1 day after confluence, the cells were treated with medium containing $10 \%$ fetal bovine serum (FBS), insulin $(10 \mu \mathrm{g} / \mathrm{ml})$, dexamethasone $(0.2 \mu \mathrm{g} / \mathrm{ml})$, and isobuthylmethylxanthine $(0.5 \mathrm{mmol} / \mathrm{l})$ for 3 days. After 3 days, this medium was replaced by a medium supplemented with $10 \% \mathrm{FBS}$ and insulin $(10 \mu \mathrm{g} / \mathrm{ml})$ and 2 days later, the medium was replaced with DMEM supplemented with $10 \%$ FBS. Cells were used for studies 0,5 , and 10 days after induction of differentiation. The cells started to store fat droplets at day 5 and almost all became adipocytes at day 10 after differentiation by microscopic observation using Sudan staining. We also confirm the differentiation with the expression of leptin mRNA by RT-PCR in each experiment as reported previously [6].

Plasmids. The 5'-flanking region of the mouse leptin gene (nt -161 to $n t+26$ ) was amplified from 3T3-L1 DNA by polymerase chain reaction. The following primers were used to amplify the leptin gene. 5'-TGCACTCGAGGCGCCTAG AATGGAG and 5'-GGGGTCTAGAGCAGCTGCTGGAGCA were used as the 5' and 3' primers, respectively. The plasmids pLepLuc-161, pLepLuc-115, pLepLuc-97, pLepLuc-70, and pLepLuc-43, contained fragments of the 5'-flanking region of the mouse leptin gene beginning at $\mathrm{nt}-161,-115,-97,-70$, and -43 , respectively. The plasmids were fused upstream to the luciferase coding region of the pGL3-Basic vector (Promega, Madison, Ws.).

Nuclear extracts. Nuclear extracts were prepared from 3T3-L1 preadipocytes (day 0) and adipocytes (day 10). Cells were harvested, washed with Dulbecco's modified phosphate-buffered saline without $\mathrm{Mg}^{2+}$ and $\mathrm{Ca}^{2+}$ ( $\mathrm{pH}$ 7.4), and, after centrifugation at $500 \cdot \mathrm{g}$, resuspended in five pellet volumes of buffer $\mathrm{A}$ [10 mmol/l HEPES-KOH (pH 7.9), 10 mmol/l KCl, 1.5 mmol/1 $\mathrm{MgCl} 2,0.1 \mathrm{mmol} / 1$ EGTA, $0.5 \mathrm{mmol} / 1$ dithiothreitol (DTT), $0.5 \mathrm{mmol} / \mathrm{l}$ phenylmethylsulfonyl fluoride (PMSF), leupeptin $(2 \mu \mathrm{g} / \mathrm{ml})$, and pepstatin A $(2 \mu \mathrm{g} / \mathrm{ml})]$ containing $0.3 \mathrm{~mol} / \mathrm{l} \mathrm{su}-$ crose and $2 \%(\mathrm{v} / \mathrm{v})$ Tween 40 . The cells were then frozen, thawed, and gently homogenized and the nuclei were isolated by centrifugation of the homogenate at $25000 \cdot g$ through a
$1.5 \mathrm{~mol} / \mathrm{l}$ sucrose cushion prepared in the same buffer. Nuclei were lysed in buffer B [10 mmol/l HEPES-KOH (pH 7.9), $420 \mathrm{mmol} / \mathrm{l} \mathrm{NaCl}, 1.5 \mathrm{mmol} / 1 \mathrm{MgCl}_{2}, 0.1 \mathrm{mmol} / \mathrm{l}$ EGTA, $10 \%$ (v/v) glycerol, $0.5 \mathrm{mmol} / \mathrm{l} \mathrm{PMSF}$, leupeptin $(2 \mu \mathrm{g} / \mathrm{ml})$, and pepstatin A $(2 \mu \mathrm{g} / \mathrm{ml})]$ and the lysate was centrifuged at $100000 \cdot \mathrm{g}$ for $1 \mathrm{~h}$. The resulting supernatant was dialysed for use in Southwestern analysis or electrophoretic mobility-shift assays (EMSA).

DNase I footprint analysis. A DNase I footprint analysis was carried out with a sure track footprinting kit (Pharmacia Biotech, Uppsala, Sweden). The Xho I-Hind III (nt -161 to $\mathrm{nt}+20)$ fragment of the mouse leptin gene was end-labelled with $\left[\gamma-{ }^{32} \mathrm{P}\right]$ ATP $(>5000 \mathrm{Ci} / \mathrm{mmol}$; Amersham, Buckinghamshire, England) and T4 polynucleotide kinase and purified by agarose gel electrophoresis. Labelled DNA fragments (30000 $\mathrm{cpm})$ were incubated with nuclear extracts in $50 \mu \mathrm{l}$ of $10 \mathrm{mmol} / \mathrm{l}$ Tris- $\mathrm{HCl}$ buffer ( $\mathrm{pH} 7.5$ ) containing $2.5 \mu \mathrm{g}$ of poly (dI-dC), $50 \mathrm{mmol} / \mathrm{l} \mathrm{NaCl}, 2.5 \mathrm{mmol} / \mathrm{l} \mathrm{MgCl}_{2}, 1 \mathrm{mmol} / \mathrm{l} \mathrm{DTT}$, $0.5 \mathrm{mmol} / \mathrm{l} \mathrm{EDTA}$, and $5 \%$ glycerol for $30 \mathrm{~min}$ at room temperature. Then the DNAs were digested with one unit of DNase I for $30 \mathrm{~s}$, extracted with phenol-chloroform, and precipitated with ethanol. As sequence markers, the corresponding DNA fragment was chemically cleaved at nucleotides $G$ and A [14]. The digested DNA samples were electrophoresed on an $8 \%$ polyacrylamide $-7 \mathrm{~mol} / \mathrm{l}$ urea gel, and the gel was then dried, exposed to an imaging plate and analysed with a Bas 2000 image analyser (Fuji, Tokyo, Japan).

EMSA. Each oligonucleotide was annealed to its complement and labelled using $\left[\alpha-{ }^{32} \mathrm{P}\right] \mathrm{dATP}$ ( $>6000 \mathrm{Ci} / \mathrm{mmol}$; Amersham) and DNA polymerase Klenow fragment. Methylated oligonucleotides were prepared by including 5-methyl deoxycytidine CED ( $\beta$-cyanoethyl-N, N-diisopropylamino) phosphoamidite (Pharmacia Biotech) during the appropriate cycle of synthesis. Each radioactive probe was incubated with $5 \mu \mathrm{g}$ of nuclear proteins from preadipocytes in $10 \mu \mathrm{l}$ of $20 \mathrm{mmol} / \mathrm{l}$ Tris- $\mathrm{HCl}$ (pH 7.5) containing $1 \mu \mathrm{g}$ of poly $(\mathrm{dI}-\mathrm{dC}), 50 \mathrm{mmol} / \mathrm{l} \mathrm{NaCl}$, $0.1 \mathrm{mmol} / 1 \mathrm{DTT}$ and $10 \%$ glycerol at room temperature. The following oligonucleotides were used in the studies as the probes and competitors:

5'-gatc ${ }^{-115}$ CTGGCCCGCTGGGTGGGGCGGGAGTTGGCGCTCGCAGGGA CTGGGG ${ }^{-70}(\mathrm{~W} 1)$,

5'-gatc ${ }^{-115}$ CTGGCCm ${ }^{5}$ CGCTGGGTGGGGm ${ }^{5}$ CGGGA GTTGGm ${ }^{5} \mathrm{CGCTm}^{5} \mathrm{C}$ GCAGGGACTGGGG ${ }^{-70}$ (M1), 5'-gatc ${ }^{-115}$ CTGGCCCGCTGGGTGGGGCGGGAGTT ${ }^{-90}$ (W2),

5'-gatc ${ }^{-115}$ CTGGCCm ${ }^{5}$ CGCTGGGTGGGGm ${ }^{5}$ CGGGAG$\mathrm{TT}^{-90}(\mathrm{M} 2)$,

5'-gatc ${ }^{-94}$ GAGTTGGCGCTCGCAGGGACTGGGG ${ }^{-70}$ (W3),

5'-gatc ${ }^{-94}$ GAGTTGGm ${ }^{5}$ CGCTm $^{5}$ CGCAGGGACTGGGG $^{-70}$ (M3)

An Sp1 consensus oligonucleotide, 5'-ATTCGATCGGGGCGGGGCGAGC, was also used as a competitor.

Southwestern analysis. Thirty micrograms of nuclear proteins from preadipocytes was dissolved in a SDS sample buffer (10\% glycerol, $70 \mathrm{mmol} / \mathrm{l} \mathrm{SDS}, 250 \mathrm{mmol} / \mathrm{l}$ Tris, $200 \mathrm{mmol} / \mathrm{l}$ DTT, pH 6.8) and boiled, then electrophoresed on a $10 \%$ SDS-polyacrylamide gel for $2 \mathrm{~h}$ at $25 \mathrm{~mA}$. Then separated proteins were electroblotted onto a nitrocellulose filter (Schleicher and Schuell, Dassel, Germany) in blotting buffer ( $25 \mathrm{mmol} / \mathrm{l}$ Tris, $0.193 \mathrm{~mol} / \mathrm{l}$ glycine) for $2 \mathrm{~h}$ at $120 \mathrm{~mA}$. The filters were incubated for $2 \mathrm{~h}$ in blocking buffer $(10 \mathrm{mmol} / \mathrm{l}$ 
HEPES pH 7.4, 1 mmol/l EDTA, $60 \mathrm{mmol} / \mathrm{l} \mathrm{NaCl}, 1 \mathrm{mmol} / \mathrm{l}$ DTT, $5 \%$ non-fat milk powder) and incubated for $12 \mathrm{~h}$ at $4{ }^{\circ} \mathrm{C}$ with labelled unmethylated or methylated probes (nt -115 to $\mathrm{nt}-70)\left(5 \cdot 10^{7} \mathrm{cpm} / \mu \mathrm{g}\right)$ in binding buffer $[10 \mathrm{mmol} / \mathrm{l} \mathrm{HEPES}$ $\mathrm{pH} 7.4,1 \mathrm{mmol} / \mathrm{l}$ EDTA, $60 \mathrm{mmol} / \mathrm{l} \mathrm{NaCl}, 1 \mathrm{mmol} / \mathrm{l} \mathrm{DTT}$, $0.25 \%$ non-fat milk powder, $5 \mu \mathrm{g} / \mathrm{ml}$ poly $(\mathrm{dI}-\mathrm{dC})]$. This incubation was carried out with or without 200 -fold molar excesses of competitors. The following oligonucleotides were used as probes and competitors: W1, W2, W3, M1, M2, and M3 that were identical to the probes and competitors used in EMSA. 5'-gatc ${ }^{-40}$ TTCAGCTCTCCGCATCTTTCCCCCTCAAGCG GGTCTCACT $^{-1}$ for the unmethylated GLUT4 probe, and 5'gatc $^{-40}$ TTCAGCTCTCm $^{5}$ CGCATCTTTCCCCCTCAAGm $^{5}$ CGGGTCTCACT $^{-1}$ for the methylated GLUT4 probe. The latter two were identical to the probes used in the experiments of the analysis of the GLUT4 gene promoter [5]. Filters were washed with several changes of washing buffer $(10 \mathrm{mmol} / \mathrm{l} \mathrm{HE}$ PES pH 7.4, 1 mmol/l EDTA, $60 \mathrm{mmol} / 1 \mathrm{NaCl}, 1 \mathrm{mmol} / \mathrm{l}$ DTT, $0.25 \%$ non-fat milk powder), then dried, exposed to an imaging plate and analysed with a Bas 2000 image analyzer (Fuji). Molecular weight was measured by a pre-stained molecular weight marker (Bio-Rad, Richmond, Calif., USA).

Sequencing of the sodium bisulfite-treated promoter. Genomic DNAs were prepared from 3T3-L1 cells on days 0,5 , and 10 after induction of differentiation, using the SDS and proteinase K method, digested with Pst I and then subjected to sequential reactions to determine $\mathrm{CpG}$ methylation pattern according to a previous study [15]. The oligonucleotide primers were synthesized based on the reported sequences of the mouse leptin gene [10]. The top strand of the promoter sequence (nt -181 to $\mathrm{nt}+20$ ) of the leptin gene was amplified using $10 \mu \mathrm{l}$ of the bisulfite-reacted DNA as a template and the oligonucleotides, 5'-GGGGAAGCTTAGGGTGTGGTTGAAGTTTTTT and 5'-GGGGTCTAGAACTACTAAAACAAAAATCCCTCC$A$, as the 5'- and 3'-primers, respectively. The underlined regions indicate a Hind III site and a $X b a$ I site added at each end of the amplified DNAs. After the digestion of these enzymes, the amplified DNAs were cloned into M13mp19 vectors for DNA sequencing.

Methylation of reporter plasmid. Methylation of the reporter plasmid was done as described [16]. Briefly, the plasmid, pLepLuc-115 or pLepLuc-70, was digested with Hind III and Xba I, and the fragment was gel-purified. Each promoter fragment was methylated in vitro with three units of SssI methylase (New England Biolabs, Beverly, Mass., USA)/ $\mu$ g of DNA in the presence of $160 \mu \mathrm{mol} / \mathrm{l} S$-adenosylmethionine at $37^{\circ} \mathrm{C}$ for $3 \mathrm{~h}$. As unmethylated control, the same fragment was incubated under the same condition without Sss I methylase. Complete methylation was verified by digesting the DNA with an excess of Hpa II restriction enzyme. The methylated or unmethylated promoter fragment was ligated into the Hind III and Xba I sites of pGL3-basic vector at $16^{\circ} \mathrm{C}$ for $30 \mathrm{~min}$. The DNA was ethanol-precipitated, and $5 \mu \mathrm{g}$ of ligated DNA was used for transfection.

Transient expression analysis. 3T3-L1 preadipocytes (day 0) and adipocytes (day 10) were transfected by electroporation (300 V; capacitance, 960 microfarad) (Gene Pulser; BioRad). The cells were harvested, washed, and resuspended at $1.5 \cdot 10^{7}$ cells $/ \mathrm{ml}^{-1}$ in $0.8 \mathrm{ml} \mathrm{PBS}$, and cotransfected with $10 \mu \mathrm{g}$ of the pLepLuc plasmids and $200 \mathrm{ng}$ of the pRL-CMV plasmids. To examine the effect of methylation on leptin gene transcription, $5 \mu \mathrm{g}$ of the mock-methylated or Sss I methylated plasmids were used. The cells were pulsed, then plated, and cultured

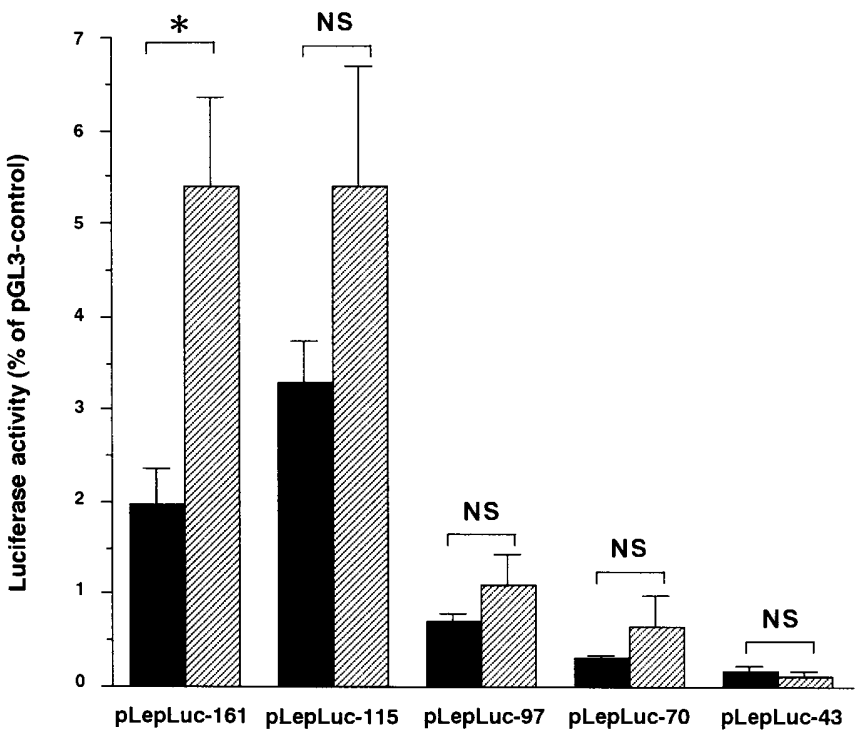

Fig. 1. Leptin promoter activity in preadipocytes and adipocytes. Deletion constructs of the leptin promoter were placed upstream of the luciferase gene and transiently transfected into preadipocytes and adipocytes. Luciferase activity, determined as described in Materials and methods, was normalized to pRL-CMV activity from a cotransfected plasmid in each extract, and expressed relative to the normalized luciferase activity of cells transfected with pGL3-Control. Standard errors were obtained from four independent experiments; Preadipo-

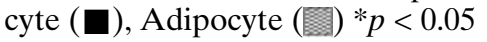

for $48 \mathrm{~h}$. Preparation of cell lysates and luciferase assays were done using a dual-luciferase assay system (Promega). A $p$ value of less than 0.05 was considered statistically significant.

\section{Results}

Promoter activity of the mouse leptin gene in preadipocytes and adipocytes. To determine the promoter activity of the mouse leptin gene, a series of 5'-deleted promoter fragments were fused to the luciferase gene in the plasmid, pGL3-basic vector, and transfected into 3T3-L1 preadipocytes and adipocytes. We found that the $161 \mathrm{bp}$ mouse leptin promoter was 2.7 -fold more active in adipocytes than in preadipocytes (Fig. 1). The activity of this promoter in preadipocytes was unexpected because these cells do not express leptin. The removal of sequences between $\mathrm{nt}-115$ and $\mathrm{nt}-97$ decreased the luciferase activity in both preadipocytes and adipocytes, suggesting the presence of an enhancer element in this region. The activity of the plasmid pLepLuc-161 above the empty vector (pGL3-basic) was 9.9-fold in the preadipocytes and 27-fold in the adipocytes.

Differential methylation of the leptin gene in 3T3-L1 cells during differentiation. To determine the methylation status of the eight $\mathrm{CpG}$ sites located at $\mathrm{nt}-159$ (CpG/-159), nt -154 (CpG/-154), nt -109 (CpG/-109), 


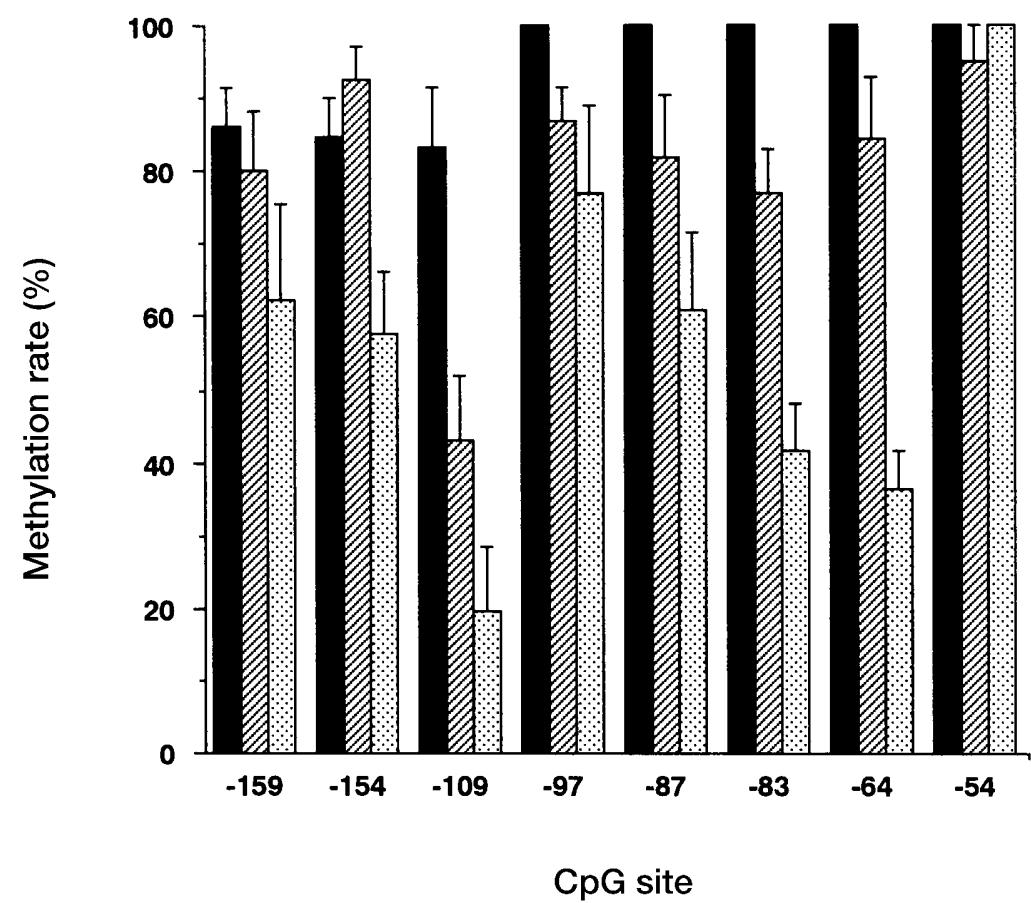

Fig. 2. The $\mathrm{CpG}$ methylation status in the leptin promoters during 3T3-L1 differentiation. The methylation status is shown as percentages of the total number of sequences analysed on days 0,5 , and 10 of 3T3-L1 preadipocyte differentiation. The values and standard errors were generated from four separate amplifications (two independent bisulfitetreatments and two separate amplifications from each bisulfite-treated DNA sample); Day $0(\mathbf{\square})$, Day 5 (滔), Day 10 ( nt -97 (CpG/-97), nt-87 (CpG/-87), nt-83 (CpG/-83), $\mathrm{nt}-64(\mathrm{CpG} /-64)$, and $\mathrm{nt}-54(\mathrm{CpG} /-54)$, the leptin gene promoter was amplified and sequenced [15]. The methylation status at each site on days 0,5 , and 10 of differentiation are shown (Fig. 2). In 3T3-L1 cells, the expression of the leptin gene is initiated during differentiation from preadipocytes to adipocytes [9]. We also examined the time-course of leptin mRNA expression at day $0,5,7$, and 10 of differentiation using RT-PCR. We could only find a faint signal at day 5 and an increased signal at day 7 and a maximum signal at day 10 (data not shown). Consistent with this differentiation-specific expression, we found that seven $\mathrm{CpG}$ sites, $\mathrm{CpG} /-$ 159, CpG/-154, CpG/-109, CpG/-97, CpG/-87, CpG/83 and $\mathrm{CpG} /-64$ showed a varying degree of demethylation during differentiation. The eighth $\mathrm{CpG}$ site, $\mathrm{CpG} /-$ 54 remained highly methylated in both preadipocytes and adipocytes.

Direct binding of nuclear protein from preadipocytes and adipocytes to the leptin gene promoter. Using DNase I footprinting analysis, we examined the binding of nuclear proteins to the leptin gene promoter. DNase I footprinting detected two protected regions within the $161 \mathrm{bp} 5$ '-flanking sequence of the leptin gene (Fig.3A, B). The proximal region (nt -63 to $n t-45$ ), which has been reported to be the $\mathrm{C} / \mathrm{EBP} \alpha$ binding site $[10,11]$, was protected only in adipocytes. In contrast, the distal region (nt -101 to $\mathrm{nt}-78$ ) was protected in both preadipocytes and adipocytes. DNase I footprinting also indicated the positions of hypersensitive sites, $\mathrm{nt}-70, \mathrm{nt}-71$, $\mathrm{nt}-76$, and $\mathrm{nt}-77$ of the sense strand, and $\mathrm{nt}-80$ of the antisense strand.
Methylation-sensitive protein binding to the 5'-flanking region of the leptin gene. The DNA fragment (nt -101 to $\mathrm{nt}-78$ ) that was protected by DNase I footprinting analysis includes two known protein-binding sites, $\mathrm{nt}-100$ to $\mathrm{nt}-95$ for $\mathrm{Sp} 1$ and $\mathrm{nt}-89$ to $\mathrm{nt}-82$ for Lp1 [12]. We utilized EMSA to assay the effect of $\mathrm{CpG}$ methylation on protein binding to the promoter region. For these experiments, we used crude nuclear extracts of preadipocytes and eight probes; W1 (nt -115 to $\mathrm{nt}-70$ without methylation), M1 (nt -115 to $\mathrm{nt}-70$ with methylation), W2 (nt -115 to nt -90 without methylation), M2 (nt -115 to $\mathrm{nt}-90$ with methylation), W3 (nt -94 to $n t-70$ without methylation) and M3 (nt -94 to nt -70 with methylation) (Fig. 4A). The $\mathrm{W} 1$ probe yielded several specific bands, all of which were excluded by the unlabelled W1 probe (Fig. 4B). In addition, the unlabelled Sp1 probe competed with all of these bands except one. The M1 probe yielded almost the identical bands as the W1 probe. All of these were effectively excluded by the unlabelled M1 probe and all but one band were excluded by the unlabelled W1 probe. This latter unchanged band could represent a methylation-dependent DNA binding protein (Fig. 4C). The M2 probe yielded several specific bands, all of which were excluded by the unlabelled, M2 probe and W2 probe. On the other hand, the M3 probe made three more bands compared with the $\mathrm{W} 3$ probe and these bands were competed out by the unlabelled M3 probe but not by the unlabelled $\mathrm{W} 3$ probe. These three bands could also represent methylation-dependent DNA binding proteins (Fig. 4D).

Southwestern analysis of protein binding to the 5'flanking region of the leptin gene. Using Southwestern 


\section{A}

Sense strand

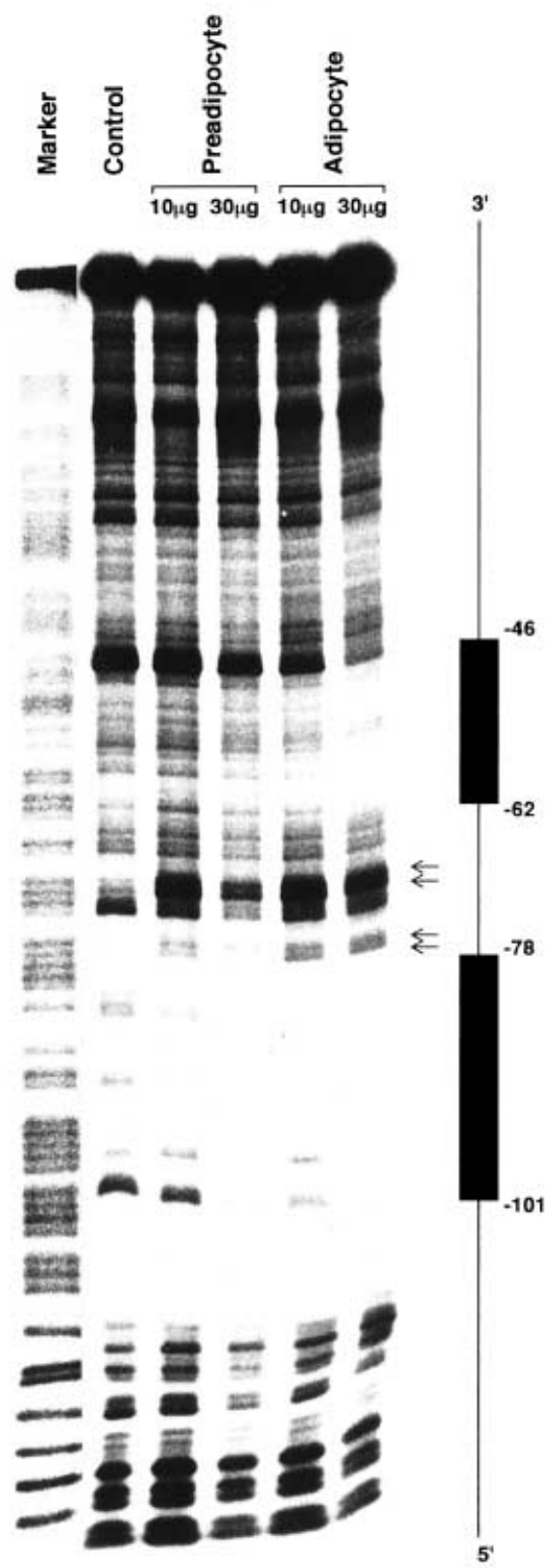

Fig.3 (A, B). Direct binding of nuclear proteins from preadipocytes and adipocytes to the leptin gene promoter. DNase I footprints were obtained with nuclear proteins from preadipocytes or adipocytes by DNase I digestion of sense strand templates (A) and antisense strand templates (B) as described in Materials and methods. The protected regions are indicated by solid bars showing 5'- and 3'- positions. The arrows on the right indicate the hypersensitive sites

analysis, we found that the $\mathrm{W} 1$ probe bound to several proteins from preadipocytes. The M1 probe bound to these proteins, as well as another protein having apparent molecular weights of $52 \mathrm{kM}_{\mathrm{r}}$ The $52 \mathrm{kM}_{\mathrm{r}}$ band was not observed by the $\mathrm{W} 2$ probe and the $\mathrm{W} 3$

\section{B Antisense strand}

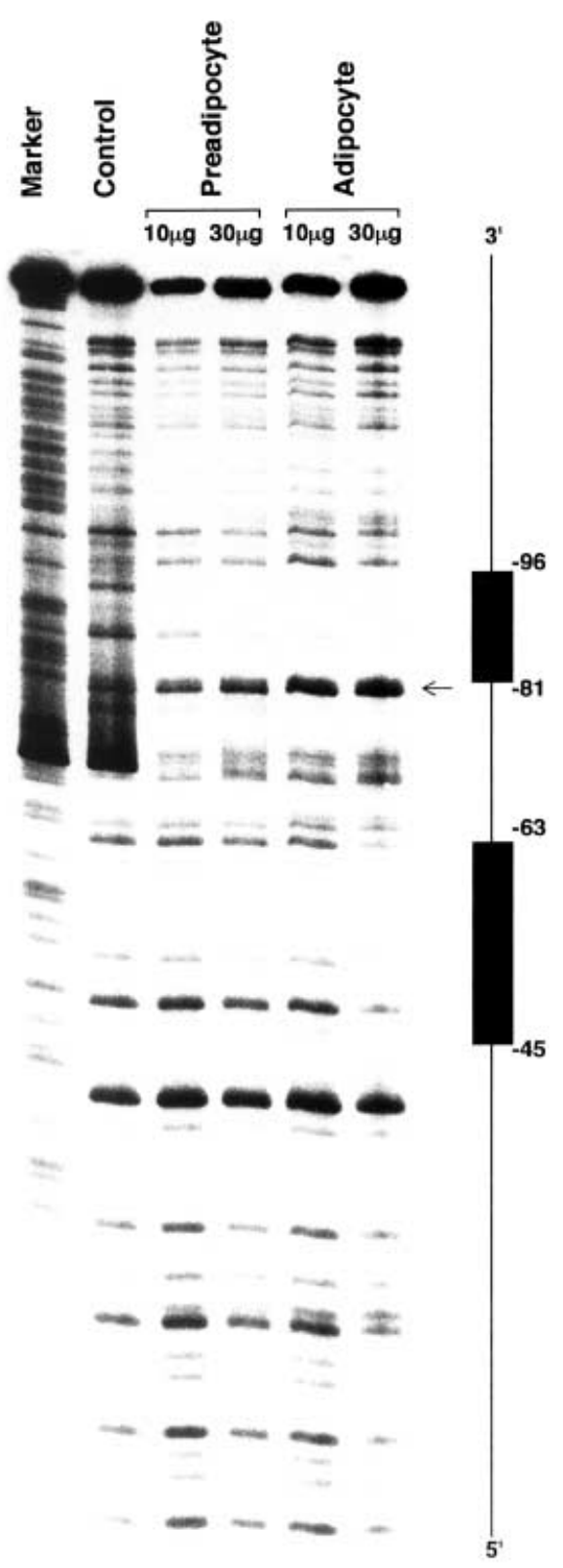

probe but observed by the M2 probe and the M3 probe (Fig. 5A). These findings suggest that the 52 $\mathrm{kM}_{\mathrm{r}}$ band could represent a methylation-dependent DNA binding protein. This protein competed with the unlabelled M1 probe, M2 probe, M3 probe and the methylated GLUT4 probe but not with the unlabelled W1 probe and the unmethylated GLUT4 probe (Fig. 5B). This $52 \mathrm{kM}_{\mathrm{r}}$ protein competed with the unlabelled M1 probe, M2 probe, M3 probe and the methylated GLUT4 probe, but not with the unlabelled W2 probe (Fig. 5C).

Effect of methylation on leptin gene transcription. To determine the effect of methylation on leptin gene transcription, fragments of the leptin gene promoter 
A

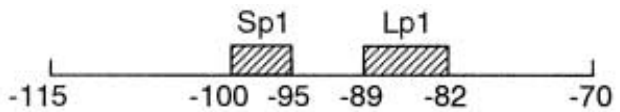

W1

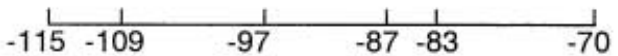

M1

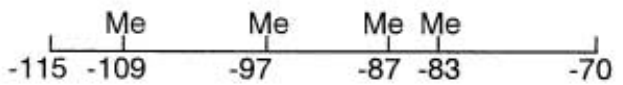

W2

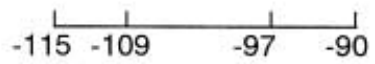

$\mathrm{M} 2$

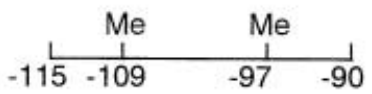

W3

M3
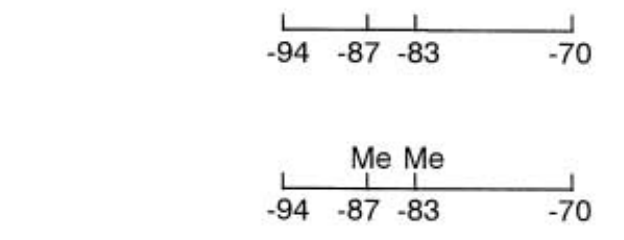

B<smiles>[R6]OC(=O)N[AlH2]</smiles>

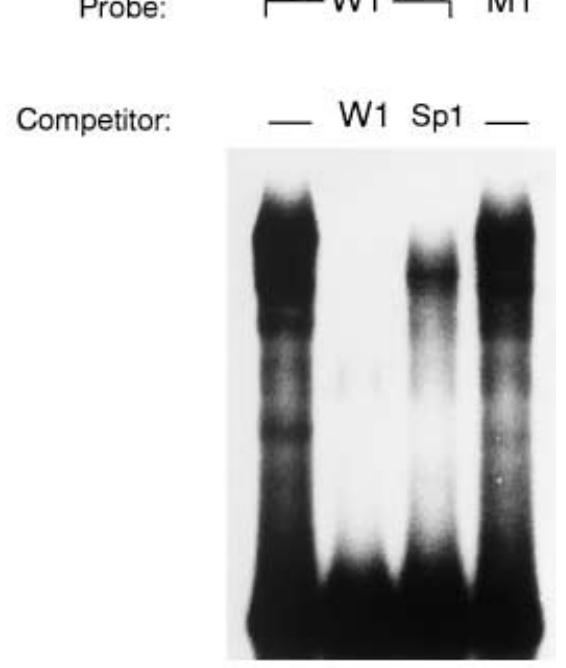

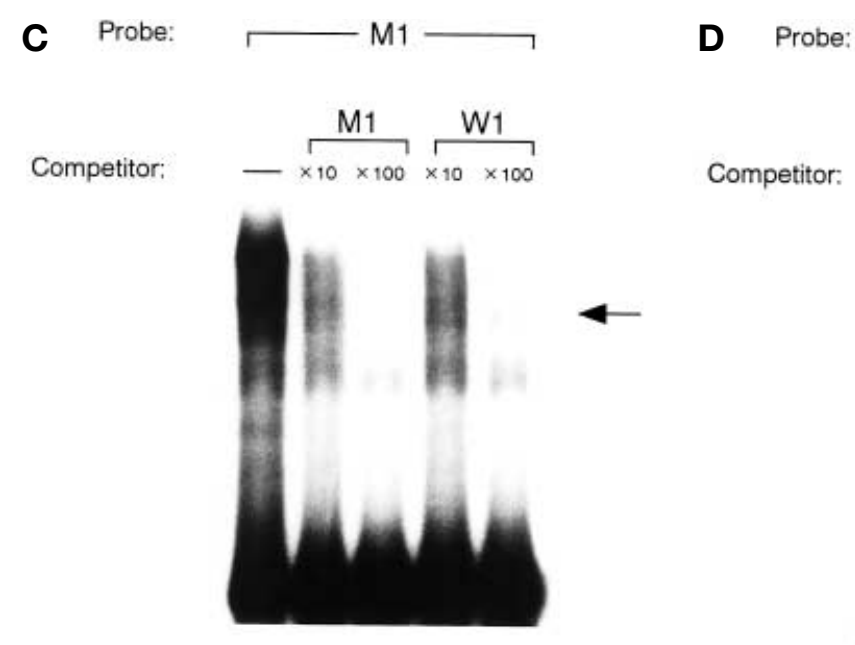

Fig. 4 (A-D). The binding to the 5'-flanking region of the leptin gene (nt -115 to nt -70 ) as calculated by EMSA. B EMSA of a reaction mixture containing nuclear proteins from preadipocytes with the W1 probe (nt -115 to $n t-70$ ) or the M1 probe in which all CpG sites had been methylated with the use of 5-methyl deoxycytidine CED phosphoamidite. A 100-fold molar excesses of the unlabelled, W1 probe or $\mathrm{Sp} 1$ probe was used as competitors. C EMSA of a reaction mixture containing the nuclear extracts of 3T3-L1 preadipocytes, the labelled M1 probe, and the indicated molar excesses of the unlabelled, W1 probe or M1 probe as competitors. The arrow indicates a methylCpG-binding protein. D EMSA of a reaction mixture containing the nuclear extracts of 3T3-L1 preadipocytes, the labelled W2 probe, M2 probe, $\mathrm{W} 3$ probe or M3 probe and the indicated molar excesses of the unlabelled W2 probe, M2 probe, W3 probe or M3 probe as competitors. The arrows indicate methyl-CpG-binding proteins were methylated with SssI methylase and ligated upstream of the luciferase gene in a reporter plasmid and the plasmids were transiently transfected into the 3T3-L1 preadipocytes. The activity of the methylated promoter extending to $\mathrm{nt}-115$ (pLepLuc-115) was $57 \%$ lower than that of the corresponding mock-methylated promoter (Fig.6). In contrast, the activity of a promoter extending to nt -70 (pLepLuc-70) was not affected by methylation. The activity of the mock methylated plasmid pLepLuc-115 above the empty vector (pGL3-basic) was 16.5-fold. 


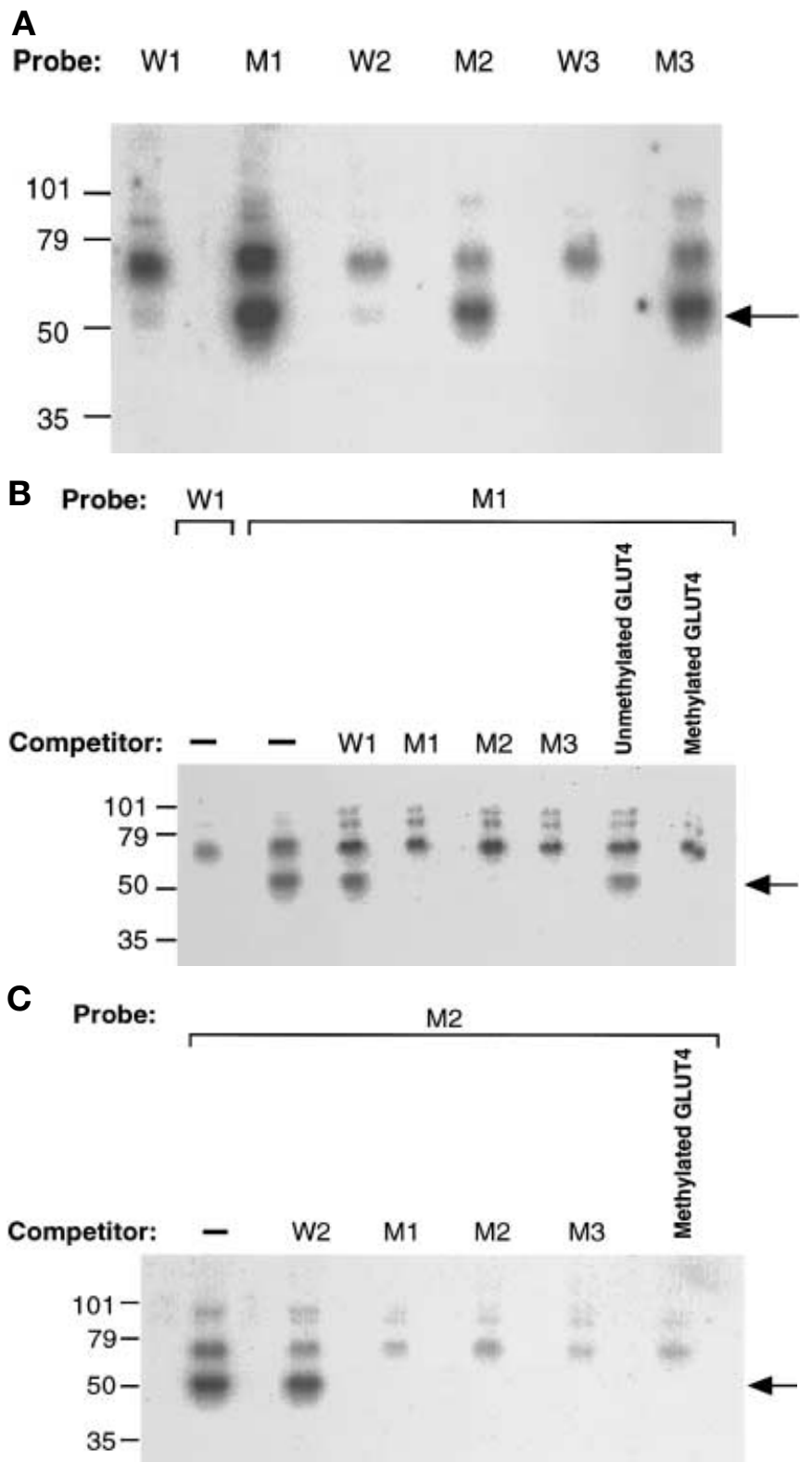

Fig. 5 (A-C). Methylation-dependent protein binding by Southwestern analysis. Preadipocyte nuclear proteins $(30 \mu \mathrm{g})$ were electrophoresed on a $10 \%$ SDS-polyacrylamide gel. The separated proteins were electroblotted onto a nitrocellulose filter, and incubated with the labelled, W1 probe, W2 probe, W3 probe, M1 probe, M2 probe or M3 probe (A). The labelled W1 probe or M1 probe was used with 200-fold molar excesses of the unlabelled W1 probe, M1 probe, M2 probe, M3 probe, unmethylated GLUT4 probe, or methylated GLUT4 probe as competitors (B). The labelled M2 probe was used with 200 -fold molar excesses of the unlabelled W2 probe, M1 probe, M2 probe, M3 probe or methylated GLUT4 probe as competitors $(\mathbf{C})$. Bars and numbers on the left indicate the sizes of the marker proteins (Bio Rad). The arrow on the right indicates a methylation-dependent protein

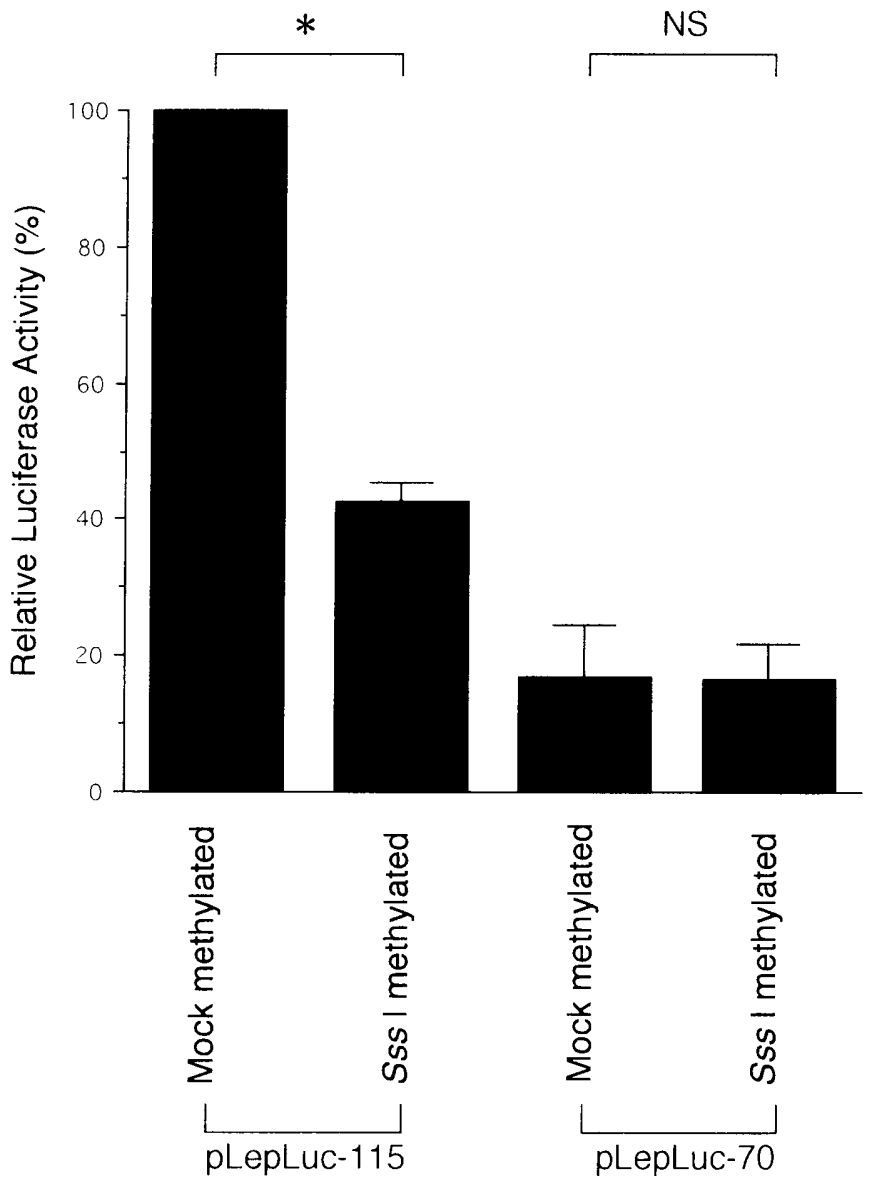

Fig. 6. Effect of methylation on leptin gene transcription. Preadipocytes were transfected with $5 \mu \mathrm{g}$ of pLepLuc-115 or pLepLuc-70 after methylation with Sss I or mock-methylation. The luciferase activity of each cell lysate was normalized to the activity of pRL-CMV from a cotransfected plasmid, and the activity of each was expressed relative to that of cells transfected with mock-methylated pLepLuc-115. Standard errors were obtained from three independent experiments $* p<0.01$

\section{Discussion}

Many genes are regulated by a combination of widely-expressed and tissue-specific transcription factors. In addition, $c i s$ element modifications, such as DNA methylation, could also be important in regulating gene expression during growth and development [17-19]. DNA methylation was recently shown to contribute to the cell-specific expression of the gene encoding L-histidine decarboxylase and cyclin D1 $[16,20]$. We have also found that demethylation of specific $\mathrm{CpG}$ sites, as well as a methylation-sensitive transcription factor, contribute to the sex-specific expression of the Cyp2d-9 gene and to the cell-specific expression of the thyrotropin receptor gene [21, 22].

The differentiation of 3T3-L1 preadipocytes to adipocytes is accompanied by the activation of numerous adipocyte-specific genes [23]. These genes are regulated by the transcription factors, such as $\mathrm{C} /$ $\mathrm{EBP} \alpha$, the proliferator-activated receptor- $\gamma 2$, prea- 
dipocyte repressor element binding protein, and the C/EBP undifferentiated protein [1-4]. We have also shown that GLUT4 gene transcription during adipocyte differentiation is regulated by the $96 \mathrm{kM}_{\mathrm{r}}$ repressor protein [24]. When we examined the mechanism underlying GLUT4 gene induction during the differentiation of 3T3-L1 cells, we also found that the methylation of specific $\mathrm{CpG}$ sites and the methylationsensitive transcription factor contribute to GLUT4 gene regulation [5]. In this study, we found that methylation of specific $\mathrm{CpG}$ sites also modulated the leptin promoter activity during adipocyte differentiation. A similar mechanism could regulate the expression of other genes induced during adipocyte differentiation.

In this study, we used the -161 bp promoter fragment of the mouse leptin gene, because the mouse leptin promoter up to -159 bp has been reported to be strongly transactivated by $\mathrm{C} / \mathrm{EBP} \alpha$ expression vector in the preadipocytes [11]. The region, however, could not bear all the important cis-acting regions for leptin induction during adipocytes differentiation as an example of the aP2 promoter [25].

The regulation of the leptin gene expression during 3T3-L1 differentiation has been reported to involve the nuclear DNA binding protein, $\mathrm{C} / \mathrm{EBP} \alpha$ $[10,11]$. The DNA-binding proteins Sp1 and Lp1, also have been shown to contribute to leptin gene expression [12]. We also showed that the binding sites for Sp1 within the leptin gene promoter are located between $n t-115$ and $n t-70$. The in vitro binding of proteins to DNA does not always reflect binding in vivo $[16,26]$. Indeed, Sp1 can bind to a promoter and activate transcription in vitro even when the $\mathrm{CpG}$ site within the Sp1 binding site is methylated. The methyl-CpG-binding protein, $\mathrm{MeCP} 2$, however, has been found to bind to DNA containing single methylated $\mathrm{CpG}$ site, and to repress Sp1-activated transcription of the human leukosialin gene when the promoter is methylated [27]. A methyl-CpG-binding protein, such as, $\mathrm{MeCP} 2$ could therefore recognize the methylated and demethylated leptin promoter and interact with Sp1 and/or other transcription factors such as Lp1 and contribute to the expression of the leptin gene during 3T3-L1 differentiation. Using EMSA, the methyl-binding proteins were observed not by the M2 probe but by the M1 and the M3 probe. Southwestern analysis, however, identified the methyl-binding protein that binds to all of the above three probes. The $52 \mathrm{kM}_{\mathrm{r}}$ band in the M2 lane is also specific. This discrepancy could come from the difference of the assay. Otherwise, the methyl-binding proteins that were observed by EMSA could be different from the $52 \mathrm{kM}_{\mathrm{r}}$ protein by Southwestern analysis which requires further study.

We have identified a $52 \mathrm{kM}_{\mathrm{r}}$ methyl-CpG-binding protein that binds to the promoter region between $\mathrm{nt}$ -115 and $n t-70$ of the leptin gene. The molecular weight of this protein differs from those of previously reported methyl-CpG-binding proteins, including MeCP2 [28-33] but is close to that of the $55 \mathrm{kM}_{\mathrm{r}}$ methyl-CpG-binding protein that binds to the GLUT4 gene promoter [5]. The $55 \mathrm{kM}_{\mathrm{r}}$ protein was observed to recognize the demethylation of the GLUT4 gene during the differentiation of 3T3-L1 preadipocytes to adipocytes. We found that the $52 \mathrm{kM}_{\mathrm{r}}$ protein competed with both the M1 probe (nt -115 to $n t-70$ ) and the methylated GLUT4 probe. We also found that the $52 \mathrm{kM}_{\mathrm{r}}$ protein bound to both $\mathrm{M} 2$ probe $(\mathrm{nt}-115$ to $\mathrm{nt}-90$ ) and $\mathrm{M} 3$ probe (nt -94 to $\mathrm{nt}-70$ ). These findings indicate that the $52 \mathrm{kM}_{\mathrm{r}}$ protein could be the same as the $55 \mathrm{kM}_{\mathrm{r}}$ protein and recognize methylated $\mathrm{CpG}$ sites regardless of their location in the DNA sequence. The $52 \mathrm{kM}_{\mathrm{r}}$ protein must not be a tissue-specific transcription factor, because this band was observed from both preadipocytes and adipocytes nuclear proteins. EMSA also showed that methylation-dependent DNA binding proteins were observed with crude nuclear extracts of preadipocytes and adipocytes (data not shown). Recently, MBD1, MBD2, MBD3, and MBD4 also have been reported as methyl-CpG-binding proteins $[34,35]$. We also examined the supershift assay using M1 and M3 probes with antibodies against MeCP2. We could not detect any supershifted band (data not shown).

In conclusion, seven of the $\mathrm{CpG}$ sites in the leptin gene promoter, located between $\mathrm{nt}-159$ and $\mathrm{nt}-64$, were highly methylated in preadipocytes but showed a varying degree of demethylation in adipocytes. In addition, the promoter region extending from $\mathrm{nt}$ -115 to $\mathrm{nt}-70$ bound to a $52 \mathrm{kM}_{\mathrm{r}}$ nuclear protein depending on the methylation status of these $\mathrm{CpG}$ sites. Since methylation of these $\mathrm{CpG}$ sites between $\mathrm{nt}-115$ and $n t-70$ prevented the activation of the leptin gene promoter, our findings suggest that $\mathrm{CpG}$ methylation in the promoter region of the mouse leptin gene between $\mathrm{nt}-115$ and $\mathrm{nt}-70$ suppresses gene transcription in preadipocytes and that demethylation during adipocytes differentiation could contribute to the expression of this gene.

Acknowledgement: We thank Dr. S. Kudo for kindly providing antibodies against $\mathrm{MeCP} 2$.

\section{References}

1. Christy RJ, Yang VW, Ntambi JM et al. (1989) Differentiation-induced expression in 3T3-L1 preadipocytes: CCAAT/ enhancer binding protein interacts with and activates the promoters of two adipocyte-specific genes. Genes Dev 3: 1323-1335

2. Swick AG, Lane MD (1992) Identification of a transcriptional repressor down-regulated durig preadipocyte differentiation. Proc Natl Acad Sci USA 89: 7895-7899

3. Vasseur-Cognet M, Lane MD (1993) CCAAT/enhancer binding protein alpha (C/EBP alpha) undifferentiated protein: a developmentally regulated nuclear protein that 
binds to the C/EBP alpha gene promoter. Proc Natl Acad Sci USA 90: 7312-7316

4. Tontonoz P, Hu E, Graves RA, Budavari AI, Spiegelman BM (1994) mPPAR gamma 2: tissue-specific regulator of an adipocyte enhancer. Genes Dev 8: 1224-1234

5. Yokomori N, Tawata M, Onaya T (1999) DNA demethylation during the differentiation of 3T3-L1 cells affects the expression of the mouse GLUT4 gene. Diabetes: 48: 685-690

6. Zhang Y, Proenca R, Maffei M, Leopold L, Friedman JM (1994) Positional cloning of the mouse obese gene and its human homologue. Nature 372: 425-432

7. Flier JS (1997) Leptin expression and action: new experimental paradigms. Proc Natl Acad Sci USA 94: 4242-4245

8. Coleman DL (1978) Obese and diabetes: two mutant genes causing diabetes- obesity syndromes in mice. Diabetologia 14: $141-148$

9. MacDougald OA, Hwang C-S, Fan H, Lane MD (1995) Regulated expression of the obese gene product (leptin) in white adipose tissue and 3T3-L1 adipocytes. Proc Natl Acad Sci USA 92: 9034-9037

10. He Y, Chen H, Quon MJ, Reitman M (1995) The mouse obese gene. J Biol Chem 270: 28887-28891

11. Hwang CS, Mandrup S, Macdougald OA, Geiman DE, Lane MD (1996) Transcriptional activation of the mouse obese (ob) gene by CCAAT/enhancer binding protein $\alpha$. Proc Natl Acad Sci USA 93: 873-877

12. Mason MM, He Y, Chen H, Quon MJ, Reitman M (1998) Regulation of leptin promoter function by $\mathrm{Sp} 1, \mathrm{C} / \mathrm{EBP}$, and a novel factor. Endocrinology 139: 1013-1022

13. McGehee RE, Ron D, Brasier AR, Habener JF (1993) Differentiation-specific element: a cis-acting developmental switch required for the sustained transcriptional expression of the angiotensinogen gene during hormonal-induced differentiation of 3T3-L1 fibroblasts to adipocytes. Mol Endocrinol 7: 551-560

14. Maxam AM, Gilbert W (1977) A new method for sequencing DNA. Proc Natl Acad Sci USA 74: 560-564

15. Frommer M, McDonald LE, Millar DS et al. (1992) A genomic sequencing protocol that yields a positive display of 5- methylcytosine residues in individual DNA strands. Proc Natl Acad Sci USA 89: 1827-1831

16. Kuramasu A, Saito H, Suzuki S, Watanabe T, Ohtsu H (1998) Mast cell-/basophil-specific transcriptional regulation of human L-hitidine decarboxylase gene by $\mathrm{CpG}$ methylation in the promoter region. J Biol Chem 273: 31607-31614

17. Cedar H (1992) DNA methylation and gene activity. Cell 70: $3-4$

18. Bird A (1992) The essentials of DNA methylation. Cell 70: 5-8

19. Tate PH, Bird AP (1993) Effects of DNA methylation on DNA-binding proteins and gene expression. Curr Opin Genet Dev 3: 226-231

20. Kitazawa S, Kitazawa R, Maeda S (1999) Transcriptional regulation of rat cyclin $\mathrm{D} 1$ gene by $\mathrm{CpG}$ methylation status in promoter region. J Biol Chem 274: 28787-28793
21. Yokomori N, Kobayashi R, Moore R, Sueyoshi T, Negishi M (1995) A DNA methylation site in the male-specific P450 (Cyp 2d-9) promoter and binding of the heteromeric transcription factor GABP. Mol Cell Biol 15: 5355-5362

22. Yokomori N, Tawata M, Saito T, Shimura H, Onaya T (1998) Regulation of the rat thyrotropin receptor gene by the methylation-sensitive transcription factor GA-binding protein. Mol Endocrinol 12: 1241-1249

23. Bernlohr DA, Bolanowaki MA, Kelly TJ, Lane MD (1985) Evidence for an increase in transcription of specific mRNAs during differentiation of 3T3-L1 preadipocytes. J Biol Chem 260: 5563-5567

24. Yokomori N, Tawata M, Onaya T (1999) A transcriptional repressor regulates mouse GLUT4 gene expression during the differentiation of 3T3-L1 cells. Diabetes 48: 2471-2474

25. Ross SR, Graves RA, Greensein A et al. (1990) A fat-specific enhancer is the primary determinant of gene expression for adipocyte P2 in vivo. Proc Natl Acad Sci USA 87: 9590-9594

26. Becker PB, Ruppert S, Schutz G (1987) Genomic footprinting reveals cell type-specific DNA binding of ubiquitous factors. Cell 51: 435-443

27. Kudo S (1998) Methyl-CpG-binding protein MeCP2 represses Sp1-activated transcription of the human leukosialin gene when the promoter is methylated. Mol Cell Biol 18: 5492-5499

28. Boyes J, Bird A (1991) DNA methylation inhibits transcription indirectly via a methyl-CpG binding protein. Cell 64: 1123-1134

29. Lewis JD, Meehan RR, Henzel WJ et al. (1992) Purification, sequence, and cellular localization of a novel chromosomal protein that binds to methylated DNA. Cell 69: 905-914

30. Jost J-P, Hofsteenge J (1992) The repressor, MDBP-2, is a member of the histone $\mathrm{H} 1$ family that binds preferentially in vitro and in vivo to methylated nonspecific DNA sequences. Proc Natl Acad Sci USA 89: 9499-9503

31. Hung L-H, Wang R, Gama-Sosa MA, Schenoy S, Ehrlich M (1984) A protein from human placental nuclei binds preferentially to 5-methylcytosine-rich DNA. Nature 308: 293-295

32. Suetake I, Tajima S, Asano A (1993) Identification of two novel mouse nuclear proteins that bind selectively to a methylated c-Myc recgnizing sequence. Nucleic Acids Res 21: 2125-2130

33. Huntriss J, Lorenzi R, Purewal A, Monk M (1997) A methylation-dependent DNA-binding activity recognizing the methylated promoter region of the mouse Xist gene. Biochem Biophys Res Commun 235: 730-738

34. Hendrich B, Bird A (1998) Identification and characterization of a family of mammalian methyl-CpG binding proteins. Mol Cell Biol 18: 6538-6547

35. Fujita N, Shimotake N, Ohki I et al. (2000) Mechanism of transcriptional regulation by methyl- $\mathrm{CpG}$ binding protein MBD1. Mol Cell Biol 14: 5107-5118 